\title{
Role of Biopsychosocial Factors on the Risk of Pneumonia in Children Under-Five Years Old at Dr. Moewardi Hospital, Surakarta
}

\author{
Nining Lestari'1,2), Harsono Salimo3), Suradi4) \\ 1)Faculty of Medicine, Muhammadiyah University Surakarta \\ 2)Masters Program in Public Health, Universitas Sebelas Maret \\ 3)Department of Pediatrics, Dr. Moewardi Hospital, Surakarta \\ 4) Department of Pulmonology, Faculty of Medicine, Sebelas Maret University
}

\begin{abstract}
Background: It is estimated that the worldwide annual incidence of child pneumonia is approximately 156 million cases. Sixty-one million new cases occure in Southeast Asia with death rate of 3.1 million deaths per year. Prevalence of infant pneumonia in Indonesia is high at $1.8 \%$ in 2013 with mortality of $0.16 \%$ in 2015 . This study aimed to determine the role of bio-psychosocial factors on the risk of pneumonia in children under-five years old.

Subjects and Method: This was an analytic observational study using cross-sectional design. The study was conducted at Dr. Moewardi Hospital, Surakarta, from April to May 2017. A sample 120 children under five years old, consisting of 30 children with pneumonia and 90 children without pneumonia, were selected for this study by fixed disease sampling. The dependent variable was incidence of pneumonia. The independent variables were nutritional status, exclusive breastfeeding, low birthweight, maternal stress, maternal education, maternal employment, family income, and home environment. Nutritional status was measured by anthropometry, while other variables were collected by questionnaire. Path analysis was employed to analyze data.

Results: Pneumonia in children under-five was directly affected by nutritional status $(b=-1.23$; 95\% $\mathrm{CI}=-2.45$ to $-0.02 ; \mathrm{p}=0.047)$, exclusive breastfeeding ( $\mathrm{b}=-1.09 ; 95 \% \mathrm{CI}=-2.26$ to $0.07 ; \mathrm{p}=$ 0.065), maternal stress $(b=1.70 ; 95 \% \mathrm{CI}=0.36$ to $3.04 ; \mathrm{p}=0.013)$, maternal education $(\mathrm{b}=-1.96$; 95\% $\mathrm{CI}=-3.31$ to $-0.61 ; \mathrm{p}=0.004)$, and home environment $(\mathrm{b}=-1.83 ; 95 \% \mathrm{CI}=-3.02$ to -0.64 ; $\mathrm{p}=0.002)$. Nutritional status was affected by maternal education $(\mathrm{b}=3.48 ; 95 \% \mathrm{CI}=1.79$ to 5.17 ; $\mathrm{p}<0.001)$, maternal stress $(\mathrm{b}=-2.55 ; 95 \% \mathrm{CI}=-4.06$ to $-1.04 ; \mathrm{p}=0.001)$, family income $(\mathrm{b}=3.26 ; \mathrm{CI}$ $95 \%=1.67$ to $4.84 ; \mathrm{p}<0.001)$, and low birthweight $(\mathrm{b}=-1.84 ; 95 \% \mathrm{CI}=-3.12$ to $-0.57 ; \mathrm{p}=0.005)$. Exclusive breastfeeding was affected by maternal education $(\mathrm{b}=0.97 ; 95 \% \mathrm{CI}=0.09$ to 1.86 ; $\mathrm{p}=0.031)$, maternal stress $(\mathrm{b}=-0.74 ; 95 \% \mathrm{CI}=-1.69$ to $0.19 ; \mathrm{p}=0.112)$, family income $(\mathrm{b}=1.39 ; \mathrm{CI}$ $95 \%=0.54$ to $2.23 ; \mathrm{p}=0.001)$, and maternal employment $(\mathrm{b}=-1.29 ; 95 \% \mathrm{CI}=-2.14$ to -0.45 ; $\mathrm{p}=0.003)$. Maternal stress was affected by home environment $(b=-1.12 ; 95 \% \mathrm{CI}=-1.96$ to -0.29 ; $\mathrm{p}=0.009$ Home environment was affected by maternal education $(\mathrm{b}=0.76 ; 95 \% \mathrm{CI}=-0.03$ to 1.54 ; $\mathrm{p}=0.059)$. Low birthweight was affected by maternal education $(\mathrm{b}=-1.21 ; 95 \% \mathrm{CI}=-2.08$ to -0.35 ; $\mathrm{p}=0.006)$ and family income $(\mathrm{b}=-1.50 ; 95 \% \mathrm{CI}=-2.35$ to $-0.66 ; \mathrm{p}<0.001)$.
\end{abstract}

Conclusion: Pneumonia in children under-five is directly affected by nutritional status children, exclusive breastfeeding, maternal education, maternal stress, and home environment.

Keywords: pneumonia, biopsychosocial factors

Correspondence: Nining Lestari. Universitas Muhammadiyah Surakarta.

Email: dr.nining.lestari.nl@gmail.com. Mobile: +6285229390353.

\section{LATAR BELAKANG}

Angka kematian balita merupakan salah satu indikator penting untuk mengukur derajat kesehatan masyarakat suatu negara.
Data global menyebutkan kematian balita pada tahun 2015 yaitu 43 kasus per 1,000 kelahiran hidup. Setiap hari di dunia, terdapat 16,000 kematian balita atau 11 
kematian balita setiap menitnya (WHO, 2016). Satu dari lima kematian balita disebabkan oleh pneumonia. Terdapat 156 juta kasus baru pneumonia balita setiap tahunnya di dunia dengan lebih dari dua juta balita meninggal karena pneumonia, sedangkan 61 juta kasus baru tersebut berada di kawasan Asia tenggara dengan angka kematian sebesar 3,1 juta kematian balita per tahun (Ghimire, 2012).

Period prevalence pneumonia balita di Indonesia berdasarkan hasil Riskesdas tahun 2007 sebesar $2.13 \%$, sedangkan pada tahun 2013 mengalami penurunan menjadi 1.8\% (Riskesdas, 2013). Angka kematian akibat pneumonia pada balita pada tahun 2015 sebesar 0.16\%, lebih tinggi dibandingkan dengan tahun 2014 yang sebesar 0,08\% (Kementerian Kesehatan RI, 2015). Prevalensi kasus pneumonia balita berdasarkan hasil pengamatan penyakit puskesmas pada tahun 2014 di kota Surakarta ditemukan sebanyak 90 kasus (1\% dari perkiraan penderita pneumoni balita), dimana perkiraan penderita pneumonia pada balita adalah 10\% dari jumlah balita (Dinas Kesehatan Kota Surakarta, 2014).

Pneumonia merupakan penyakit infeksi yang menyerang parenkim paru, dan menjadi penyebab utama kematian balita di dunia, terutama negara-negara berkembang dan negara miskin. Balita merupakan kelompok umur yang rentan terhadap masalah gizi dan penyakit sehingga mengakibatkan pertumbuhan dan perkembangan menjadi terganggu bahkan dapat menyebabkan kematian (WHO, 2016).

Angka kejadian pneumonia yang tinggi tidak terlepas dari faktor risiko pneumonia yang beragam. Konsep yang berkembang antara lain adalah konsep biopsikososial. Paradigma biopsikososial menerapkan konsep suatu penyakit dalam populasi dipengaruhi oleh faktor biologis, psikologis dan faktor sosial (Soetjiningsih, 2012).

Konsep biopsikososial dalam pendekatan suatu penyakit dapat memberikan suatu gambaran yang menyeluruh tentang munculnya suatu kondisi sakit yang dihubungkan dengan faktor individu, lingkungan dan psikologi yang terkait di dalamnya (Hatala, 2012). Kasus pneumonia, secara biologis pneumonia berkaitan dengan agen penyakit seperti virus dan bakteri, dari faktor individu antara lain usia, jenis kelamin, imunisasi, pemberian ASI eksklusif, BBLR (Berat Bayi Lahir Rendah), dan status gizi (Rudan et al., 2008). Pneumonia secara psikologis dipengaruhi secara tidak langsung oleh stres psikologis ibu, dimana stres pada ibu mempengaruhi pemberian ASI eksklusif pada balita dan pola perawatan balita (Dozier et al, 2012; Han et al., 2015).

Faktor sosial pada kejadian pneumonia dapat dipicu oleh lingkungan yang tidak sehat, seperti ventilasi yang buruk, polusi dalam rumah, kepadatan penghuni, jenis lantai rumah. Ketiga faktor tersebut akan berkontribusi secara sinergis dalam terjadinya gangguan kesehatan seseorang. Penatalaksanaan pneumonia balita dapat lebih komprehensif karena melibatkan faktor biopsikososial (Hatala, 2012; Jackson et al., 2013).

\section{SUBJEK DAN METODE \\ 1. Desain Studi Penelitian}

Metode penelitian yang digunakan dalam penelitian ini adalah studi analitik observasional dengan pendekatan case control. Waktu penelitian dilakukan pada bulan April-Mei 2017 di RSUD Dr. Moewardi, Surakarta, Jawa Tengah.

\section{Populasi dan Teknik Sampling}

Populasi kasus dari penelitian ini adalah ibu yang mempunyai balita (usia 2-60 bulan) dengan pneumonia yang berkunjung 
Journal of Maternal and Child Health (2017), 2(2): 162-175

https://doi.org/10.26911/thejmch.2017.02.02.07

ke Poliklinik Anak RSUD Dr. Moewardi Surakarta pada bulan April-Mei 2017. Populasi kontrol adalah ibu yang mempunyai balita (usia 2-6o bulan) dengan pneumonia yang berkunjung ke Poliklinik Anak RSUD Dr. Moewardi Surakarta pada bulan April-Mei 2017. Kriteria eksklusi adalah ibu yang mempunyai balita dengan kelainan kongenital berat dan kegawatan. Pengambilan subjek pada penelitian ini ditetapkan dengan fixed disease sampling.

\section{Variabel Penelitian}

Variabel dependen penelitian ini adalah pneumonia balita. Sedangkan variabel independen adalah status gizi balita, ASI eksklusif, BBLR, stres ibu, pendidikan ibu, pekerjaan ibu, pendapatan keluarga dan lingkungan rumah.

\section{Definisi Operasional Variabel}

Definisi operasional variabel pneumonia balita adalah balita yang diagnosis sesuai kriteria kasus pneumonia balita oleh dokter di poliklinik anak RSUD Dr. Moewardi Surakarta. Variabel status gizi balita adalah penentuan status gizi berdasarkan berat badan (BB) menurut panjang badan (PB) atau tinggi badan (TB).

BBLR (Berat Bayi Lahir Rendah) adalah berat bayi lahir $\leq 2,500$ gram. ASI eksklusif adalah pemberian ASI pada bayi selama 6 bulan tanpa makanan pendamping. Pendapatan keluarga merupakan pemasukan keluarga akibat proses ekonomi atau sumber ekonomi keluarga yang diterima dalam kurun waktu satu bulan. Pendidikan ibu adalah pendidikan formal terakhir ibu sampai terakhir dengan mendapatkan ijasah. Pekerjaan adalah kegiatan yang dilakukan selain sebagai ibu rumah tangga, diluar rumah dan menghasilkan pendapatan. Stres ibu adalah stres selama 12 bulan terakhir yang dipicu oleh peristiwa kehidupan (life event). Lingkungan rumah adalah kondisi rumah yang meliputi ada tidaknya anggota keluarga yang merokok, paparan asap dapur, ada tidaknya ventilasi, kepadatan penghuni, kondisi lantai dan sanitasi rumah.

\section{Instrumen Penelitian}

Instrumen penelitian untuk variabel pneumonia balita dilihat dari rekam medis, dibedakan menjadi pneumonia dan tidak pneumonia. Variabel status gizi diukur menggunakan pedoman status gizi dari kemenkes RI, dibagi menjadi gizi kurang apabila $z$ score $\leq-2 \mathrm{SD}$, gizi baik bila $z$ score $\geq-2$ SD. BBLR diketahui dari kuesioner dan rekam medis, dibagi menjadi BBLR dan tidak BBLR.

Variabel ASI eksklusif diukur dengan kuisioner dibagi menjadi tidak ASI eksklusif dan ASI eksklusif. Pendidikan ibu didapatkan dari kuisioner, dibedakan menjadi pendidikan rendah dan pendidikan tinggi. Pendapatan keluarga, didapatkan dari kuisioner, dibedakan menjadi <UMR dan $\geq$ UMR. Pekerjaan ibu didapatkan dari kuisioner, dibedakan menjadi ibu tidak bekerja dan ibu bekerja di luar rumah. Variabel stres ibu diukur dengan skala Holmes dan Rahe, dibedakan menjadi stres (skor $\geq 150$ ) dan tidak stres (skor $<150$ ). Variabel lingkungan rumah diukur menggunakan kuesioner yang telah diuji validitas dan reliabilitasnya dengan hasil $r$ hitung $\geq 0.35$ ( $\geq 0.20$ ), serta Cronbach's Alpha 0.91 $(\geq 0.70)$. Variabel lingkungan dibagi menjadi lingkungan baik (skor $\geq 8$ ) dan tidak baik (skor<8).

\section{Analisis Data}

Analisis yang digunakan dalam penelitian ini yaitu analisis jalur STATA 13. Analisis jalur merupakan teknik analisis yang digunakan untuk mengetahui pengaruh suatu variabel eksogen terhadap variabel endogen baik yang mempengaruhi secara langsung maupun tidak langsung. Besarnya pengaruh variabel eksogen terhadap variabel endogen dapat dilihat dari nilai koefisien jalur, semakin besar koefisien jalur maka 
akan semakin besar pula pengaruh yang diberikan dari variabel itu.

\section{HASIL}

\section{Analisis Univariat}

Tabel 1 menunjukkan karakteristik subjek penelitian berdasarkan usia subjek. Ibu yang berusia <35 tahun lebih banyak daripada subjek ibu yang berusia kurang dari 35 tahun dengan persentase masingmasing sebesar $70.8 \%$ dan $29.2 \%$.

Dilihat dari tingkat pendidikan ibu yang berpendidikan SMA mendominasi yaitu sebesar 55\%. Ibu yang tidak bekerja/

Tabel 1. Karakteristik subjek penelitian

\begin{tabular}{llcc}
\hline \multicolumn{1}{c}{ Karakteristik Subjek } & \multicolumn{1}{c}{ Kriteria } & Frekuensi & (\%) \\
\hline Umur Ibu & $<35$ Tahun & 85 & 70.8 \\
Pendidikan Ibu & $\geq 35$ Tahun & 35 & 29.2 \\
& SD & 9 & $7 \cdot 5$ \\
& SMP & 29 & 24.2 \\
& SMA & 66 & 55.0 \\
& D1 & 2 & 1.7 \\
& D3 & 7 & 5.8 \\
Status Pekerjaan Ibu & S1 & 7 & 5.8 \\
Pendapatan Keluarga & Tidak bekerja/ bekerja dirumah & 71 & 59.2 \\
& Bekerja di luar rumah & 49 & 40.8 \\
Usia anak & < UMR & 50 & 41.7 \\
& $\geq$ UMR & 70 & 58.3 \\
Jenis Kelamin Anak & 2-12 bulan & 40 & 33.3 \\
& 13-24 bulan & 61 & 50.8 \\
& 25-6o bulan & 19 & 15.8 \\
& Laki-laki & 65 & 54.2 \\
\hline
\end{tabular}

\section{Analisis Bivariat}

Analisis bivariat digunakan untuk melihat adanya hubungan variabel independen dengan variabel dependen yang dianalisis menggunakan uji Chi square dan perhitungan odds ratio (OR) dengan tingkat kepercayaan (CI) sebesar 95\%.

Tabel 3 hasil analisis uji Chi Square menunjukkan ada hubungan signifikan antara BBLR dengan kejadian pneumonia dengan nilai dan $(\mathrm{OR}=3.14$; CI 95\%=1.34 bekerja di rumah lebih banyak yaitu 59.2\% dibanding yang bekerja di luar rumah (40.8\%).

Karakteristik anak yang dipaparkan adalah jenis kelamin dan usia anak. Subjek yang memiliki balita pneumonia dan non pneumonia dengan kriteria terdiri dari 65 anak laki-laki dan 55 anak perempuan, sebanyak $50.8 \%$ berusia $13-24$ bulan, $33.3 \%$ usia 2-12 bulan dan $15.8 \%$ usia $25-60$ bulan. hingga 7.39; $\mathrm{p}=0.008)$. Balita dengan berat lahir <2,500 gram (BBLR) mempunyai risiko 3.14 kali lebih besar untuk mengalami kejadian pneumonia.

Hasil analisis bivariat menunjukkan ada hubungan yang bermakna antara pneumonia balita dengan status gizi $(\mathrm{OR}=0.1$; CI 95\%=0.04 hingga 0.26; $\mathrm{p}<0.001)$. Balita yang memiliki satus gizi buruk mempunyai risiko 0.1 kali lebih besar untuk mengalami kejadian pneumonia. 
Ada hubungan yang bermakna antara pneumonia balita dengan ASI eksklusif $(\mathrm{OR}=0.18$; CI $95 \%=0.08$ hingga 0.45 ; $\mathrm{p}<0.001$ ). Balita yang tidak mendapatkan ASI eksklusif mempunyai risiko 0.18 kali lebih besar untuk mengalami kejadian pneumonia.

Ada hubungan yang bermakna antara pneumonia balita dengan pendidikan ibu $(\mathrm{OR}=0.13 ; \mathrm{CI} 95 \%=0.05$ hingga $0.33 ; \mathrm{p}<$ o.001). Ibu pendidikan <SMA menyebabkan balita berisiko 0.13 kali lebih besar mengalami kejadian pneumonia.

Ada hubungan yang bermakna antara pneumonia balita dengan pendapatan keluarga $(\mathrm{OR}=2.37$; $\mathrm{CI} 95 \%=1.02$ hingga $5.49 ;$ $\mathrm{p}=0.042)$. Ibu yang bekerja di luar rumah dapat menyebabkan balitanya berisiko 2.37 kali lebih besar mengalami kejadian pneumonia.

Tabel 2. Analisis bivariat variabel dependen dan independen

\begin{tabular}{|c|c|c|c|c|c|c|c|c|c|}
\hline \multirow{3}{*}{ Variabel } & \multicolumn{4}{|c|}{ Pneumonia } & \multirow{2}{*}{\multicolumn{2}{|c|}{ Total }} & \multirow{3}{*}{$\mathbf{O R}$} & \multirow{3}{*}{ CI (95\%) } & \multirow{3}{*}{$\mathbf{p}$} \\
\hline & \multicolumn{2}{|c|}{ Ya } & \multicolumn{2}{|c|}{ Tidak } & & & & & \\
\hline & $\underline{\mathbf{n}}$ & $\%$ & $\mathbf{n}$ & $\%$ & $\mathbf{n}$ & $\%$ & & & \\
\hline BBLR & & & & & & & & 1.34 hingga & \\
\hline Tidak $(\geq 2,500 \mathrm{~g})$ & 14 & 17.5 & 66 & 82.5 & 80 & 100 & 3.14 & 7.39 & 0.008 \\
\hline $\mathrm{Ya}(<2,500 \mathrm{~g})$ & 16 & 40.0 & 24 & 60.0 & 40 & 100 & & & \\
\hline Status Gizi & & & & & & & & & \\
\hline Buruk & 20 & 57.1 & 15 & 42.9 & 35 & 100 & 0.10 & $0.04-0.26$ & $<0.001$ \\
\hline Baik & 10 & 11.8 & 75 & 88.2 & 85 & 100 & & & \\
\hline ASI Eksklusif & & & & & & & & & \\
\hline Tidak & 21 & 43.8 & 27 & 56.3 & 48 & 100 & 0.18 & $0.08-0.45$ & $<0.001$ \\
\hline Ya & 9 & 12.5 & 63 & 87.5 & 72 & 100 & & & \\
\hline Pendidikan Ibu & & & & & & & & & \\
\hline$<$ SMA & 20 & 51.3 & 19 & 48.3 & 39 & 100 & 0.13 & $0.05-0.33$ & $<0.001$ \\
\hline$\geq$ SMA & 10 & 12.3 & 71 & 87.7 & 81 & 100 & & & \\
\hline Pekerjaan Ibu & & & & & & & & & \\
\hline Tidak bekerja & 13 & 18.3 & 58 & 81,7 & 71 & 100 & 2.37 & $1.02-5.49$ & 0.042 \\
\hline Bekerja di luar rumah & 17 & 34,7 & 32 & 65.3 & 49 & 100 & & & \\
\hline Pendapatan & & & & & & & & & \\
\hline Keluarga & & & & & & & & & \\
\hline UMR(<Rp.1500.000) & 20 & 40.0 & 30 & 60.0 & 50 & 100 & 0.25 & $0.10-0.60$ & 0.001 \\
\hline $\mathrm{UMR}(\geq \mathrm{Rp} .1500 .000)$ & 10 & $14 \cdot 3$ & 60 & 85.7 & 70 & 100 & & & \\
\hline Lingkungan Rumah & & & & & & & & & \\
\hline Buruk & 22 & 50.0 & 22 & 50.0 & 44 & 100 & 0.12 & $0.05-0.30$ & $<0.001$ \\
\hline Baik & 8 & 10.5 & 68 & 89.5 & 76 & 100 & & & \\
\hline Stres Ibu & & & & & & & & & \\
\hline Tidak & 14 & 16.5 & 71 & 83.5 & 85 & 100 & 4.27 & $1.78-10.28$ & 0.001 \\
\hline $\mathrm{Ya}$ & 16 & 45.7 & 19 & 54.3 & 35 & 100 & & & \\
\hline
\end{tabular}
keluarga $(\mathrm{OR}=0.25$; CI 95\%=0.10 hingga o.33; $\mathrm{p}=0.060)$. Ibu yang memiliki pendapatan $\geq$ UMR menurunkan risiko balita terkena pneumonia sebesar 0.25 kali.

Ada hubungan yang bermakna antara pneumonia balita dengan lingkungan rumah $(\mathrm{OR}=0.12 ;$ CI 95\%=0.05 hingga o.30; p<0.001). Balita yang tinggal di lingkungan yang baik menurunkan risiko terkena pneumonia sebesar 0.12 kali.

Ada hubungan yang bermakna antara pneumonia balita dengan status gizi (OR= 4.28; CI 95\%=1.78 hingga 10.28; $\mathrm{p}=0.001$ ). Balita yang tinggal di lingkungan yang buruk mempunyai risiko 4.28 kali lebih besar untuk mengalami pneumonia. 
3. Analisis Multivariat

Tabel 4 menunjukkan pengaruh secara langsung status gizi balita, lingkungan rumah dan ASI eksklusif terhadap kejadian pneumonia balita.

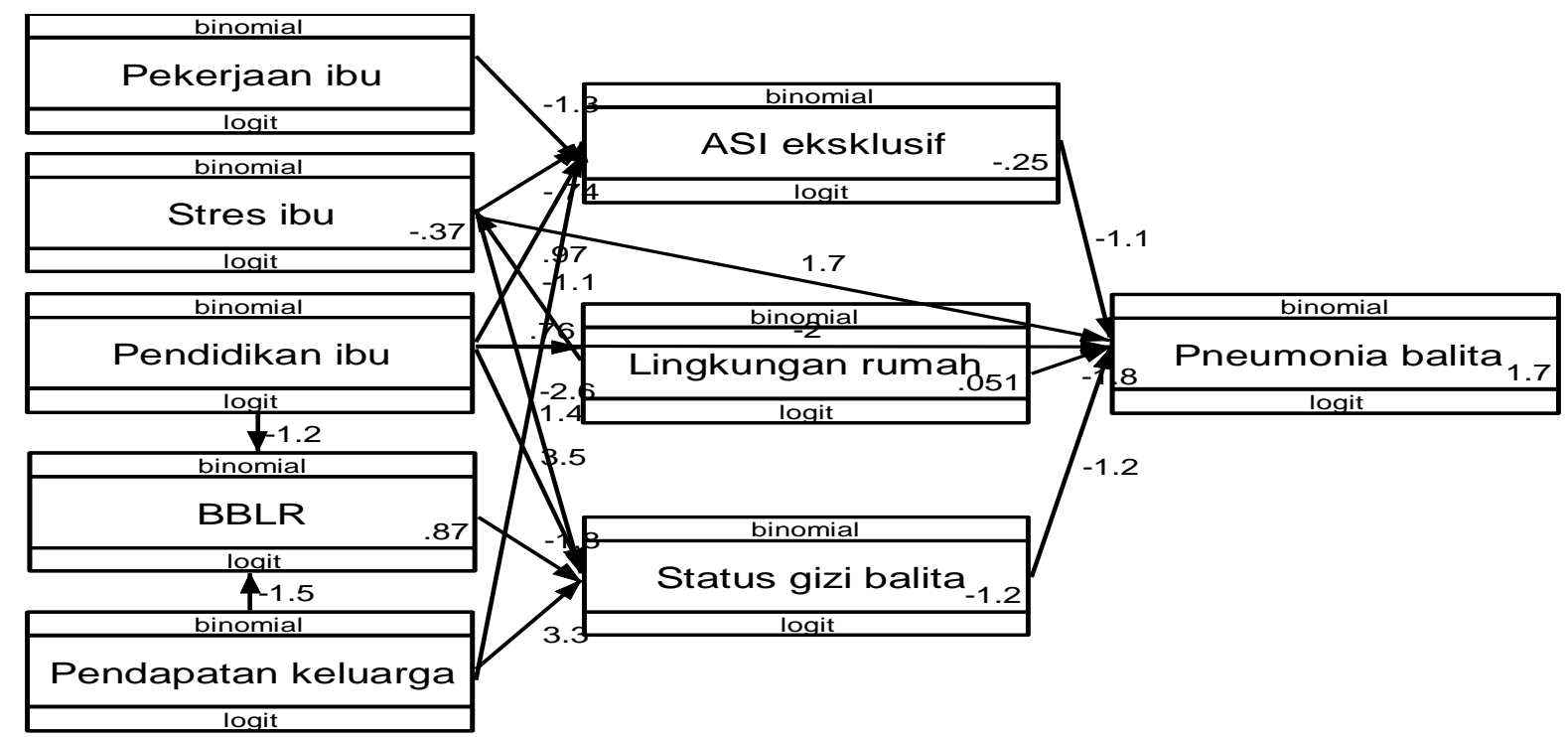

Gambar 1. Model struktural analisis jalur

Tabel 4. Hasil uji analisis jalur determinan pneumonia balita di RSUD Dr. Moewardi, Surakarta

\begin{tabular}{|c|c|c|c|c|}
\hline \multirow{2}{*}{ Variabel } & \multirow{2}{*}{ Koefisien jalur (b) } & \multicolumn{2}{|c|}{ CI 95\% } & \multirow{2}{*}{$\mathbf{p}$} \\
\hline & & Batas bawah & Batas Atas & \\
\hline \multicolumn{5}{|l|}{ Pneumonia } \\
\hline Asi Eksklusif & -1.09 & -2.26 & 0.07 & 0.065 \\
\hline Lingkungan Rumah & -1.83 & -3.02 & -0.64 & 0.002 \\
\hline Status Gizi & -1.23 & -2.45 & -0.02 & 0.047 \\
\hline Stres Ibu & 1.70 & 0.36 & 3.04 & 0.013 \\
\hline Pendidikan Ibu & -1.96 & $-3 \cdot 31$ & -0.61 & 0.004 \\
\hline \multicolumn{5}{|l|}{ Status Gizi } \\
\hline Stres Ibu & -2.55 & -4.06 & -1.04 & 0.001 \\
\hline Pendidikan Ibu & 3.48 & 1.79 & 5.17 & $<0.001$ \\
\hline Pendapatan Keluarga & 3.26 & 1.67 & 4.84 & $<0.001$ \\
\hline BBLR & -1.84 & -3.12 & -0.57 & 0.005 \\
\hline \multicolumn{5}{|l|}{ ASI Eksklusif } \\
\hline Stres Ibu & -0.74 & -1.69 & 0.19 & 0.121 \\
\hline Pendidikan Ibu & 0.97 & 0.09 & 1.86 & 0.031 \\
\hline Pendapatan Keluarga & 1.39 & 0.54 & 2.23 & $<0.001$ \\
\hline Pekerjaan Ibu & -1.29 & -2.14 & -0.45 & 0.003 \\
\hline \multicolumn{5}{|l|}{ Stres Ibu } \\
\hline Lingkungan Rumah & -1.12 & -1.96 & -0.29 & 0.009 \\
\hline \multicolumn{5}{|l|}{ Lingkungan Rumah } \\
\hline Pendidikan Ibu & 0.76 & -0.03 & 1.54 & 0.059 \\
\hline \multicolumn{5}{|l|}{ BBLR } \\
\hline Pendidikan Ibu & -1.21 & -2.08 & -0.35 & 0.006 \\
\hline Pendapatan Keluarga & -1.50 & -2.35 & -0.66 & $<0.001$ \\
\hline
\end{tabular}


Journal of Maternal and Child Health (2017), 2(2): 162-175

https://doi.org/10.26911/thejmch.2017.02.02.07

Terdapat pengaruh ASI Eksklusif terhadap kejadian pneumonia balita dan hasil tersebut signifikan. Balita yang mendapatkan ASI eksklusif memiliki logodd untuk terkena pneumonia sebesar 1.09 lebih kecil daripada balita yang tidak mendapatkan ASI eksklusif $(\mathrm{b}=-1.09 ; \quad \mathrm{CI} \quad 95 \%=-2.26$ hingga $0.07 ; p=0.065$ ).

Terdapat pengaruh secara langsung lingkungan terhadap kejadian pneumonia balita dengan hasil signifikan. Balita yang tinggal di lingkungan yang baik memiliki logodd untuk terkena pneumonia 1.83 lebih kecil daripada balita yang tinggal di lingkungan rumah yang buruk $(\mathrm{b}=-1.83$; CI $95 \%=-3.02$ hingga $-0.64 ; \mathrm{p}=0.002$ ).

Terdapat pengaruh secara langsung status gizi anak terhadap kejadian pneumonia balita dengan hasil signifikan. Balita dengan status gizi baik memiliki logodd untuk terkena pneumonia 1.23 lebih kecil dari balita status gizi yang kurang $(b=-1.23$; CI 95\% $=-2.45$ hingga $-0.02 ; \mathrm{p}=0.047$ ).

Terdapat pengaruh secara langsung stres ibu terhadap kejadian pneumonia balita dengan hasil signifikan. Balita dari ibu yang mengalami stres psikologis memiliki logodd untuk terkena pneumonia 1.70 lebih besar daripada balita dari ibu yang tidak mengalami stres $(b=1.70$; $C I \quad 95 \%=0.36$ hingga 3.04; $p=0.013$ ).

Terdapat pengaruh secara langsung pendidikan ibu terhadap kejadian pneumonia balita dengan hasil signifikan. Balita dari ibu yang berpendidikan lebih dari SMA memiliki logodd untuk terkena pneumonia 1.96 lebih kecil daripada balita dari ibu yang berpendidikan kurang dari SMA $(\mathrm{b}=-$ 1.96; CI $95 \%=-3.31$ hingga $-0.61 ; p=$ $0.004)$.

ASI eksklusif dipengaruhi oleh pendidikan ibu, pendapatan keluarga, stres ibu, dan pekerjaan ibu. Ibu yang berpendidikan lebih dari SMA memiliki logodd untuk memberikan ASI eksklusif yaitu 0.97 kali lebih besar daripada ibu yang berpendidikan kurang dari SMA $(\mathrm{b}=0.97$; $\mathrm{CI} 95 \%=$ 0.09 hingga 1.86; $\mathrm{p}=0.031$ ). Ibu dengan pendapatan lebih dari UMR memiliki logodd untuk memberikan ASI eksklusif yaitu 1.39 lebih besar daripada ibu dengan pendapatan <UMR $(\mathrm{b}=1.39$; CI 95\%= 0.54 hingga 2.23; $\mathrm{p}<0.001$. Ibu dengan stres psikologis memiliki logodd untuk memberikan ASI eksklusif yaitu 0.74 lebih kecil daripada ibu yang tidak mengalami stres $(\mathrm{b}=-0.74$; CI 95\%= -0.16 hingga $-1.04 ; \mathrm{p}=$ o.121). Ibu yang bekerja di luar rumah memiliki logodd untuk mengalami memberikan ASI eksklusif 1.29 lebih kecil daripada ibu dengan yang tidak bekerja $(b=-1.29$; CI $95 \%=-2.14$ hingga $-0.45 ; \mathrm{p}<0.001)$.

Status gizi dipengaruhi oleh pendidikan ibu, stres ibu, pendapatan keluarga dan BBLR. Ibu yang berpendidikan lebih dari SMA memiliki logodd untuk mempunyai balita dengan status gizi baik yaitu 3.48 lebih besar daripada ibu yang berpendidikan kurang dari SMA ( $b=3.48$; CI $95 \%=1.79$ hingga 5.17; $\mathrm{p}<0.001)$. Ibu dengan pendapatan lebih dari UMR memiliki logodd untuk mempunyai balita dengan gizi baik yaitu 3.26 lebih besar daripada ibu dengan pendapatan $<$ UMR $(b=3.26$; CI $95 \%=1.67$ hingga 4.84; $\mathrm{p}<0.001$ ). Ibu dengan stres psikologis memiliki logodd untuk mempunyai balita dengan gizi baik yaitu 2.25 lebih kecil daripada ibu yang tidak mengalami stres $(b=-2.25$; CI 95\%= -4.06 hingga 1.04; $\mathrm{p}=0.001$ ). Bayi dengan BBLR memiliki logodd untuk menderita status gizi kurang sebesar 1.84 kali daripada bayi dengan berat badan lahir normal $(\mathrm{b}=-\mathbf{1 . 8 4}$; CI 95\%=13.12-hingga -0.57; $\mathrm{p}=0.005$ ).

BBLR dipengaruhi oleh pendidikan ibu dan pendapatan keluarga. Ibu dengan pendapatan $\geq$ UMR memiliki logodd untuk mempunyai balita BBLR yaitu 1.50 lebih kecil daripada ibu dengan pendapatan $<$ UMR (b=-1.50; CI 95\%=-2.35 hingga - 
0.06; p<0.001). Ibu dengan pendidikan $\geq$ SMA menurunkan kejadian pneumonia sebesar 1.21 kali daripada ibu dengan pendidikan <SMA $(\mathrm{b}=-1.21$; CI 95\%=-2.08 hingga -0.35; $\mathrm{p}<0.006)$.

Stres ibu dipengaruhi oleh lingkungan rumah. Ibu dengan lingkungan rumah baik memiliki logodd untuk mengalami stres 1.12 lebih kecil daripada ibu dengan lingkungan rumah uang buruk $(b=-1.12$; $C I$ $95 \%=-1.96$ hingga $-0.29 ; \mathrm{p}=0.009)$.

Lingkungan rumah dipengaruhi oleh pendidikan ibu. Ibu yang berpendidikan $\geq$ SMA memiliki logodd untuk memiliki lingkungan rumah yang baik yaitu 0.76 kali lebih besar daripada ibu yang berpendidikan < SMA $(b=0.76$; CI 95\%=-0.03 hingga $1.54 ; p=0.059)$.

\section{PEMBAHASAN}

\section{Pengaruh status gizi anak terhadap kejadian pneumonia balita.}

Penelitian ini menunjukkan bahwa terdapat pengaruh secara langsung antara status gizi balita dengan kejadian pneumonia balita. Hasil penelitian ini didukung oleh Hadisuwarno et al., (2015) bahwa salah satu faktor host yang berperan dalam kejadian pneumonia adalah status gizi. Malnutrisi/ status gizi kurang <-2 SD meningkatkan risiko pneumonia sebesar 3.44 kali $(\mathrm{OR}=3.44$; $\mathrm{CI} 95 \%=2.12$ hingga 5.58; $\mathrm{p}<0.001)$.

Status gizi baik dapat meningkatkan sistem imun untuk melawan berbagai mikroorganisme yang menyerang tubuh. Senyawa makro dan mikronutrien dalam tubuh dapat mencegah terjadinya infeksi contohnya vitamin A, zink dan vitamin $\mathrm{D}$. Pengaruh nutrisi dalam melawan infeksi melalui berbagai macam mekanisme tubuh, salah satu mekanismenya adalah kandungan antioksidan tinggi dalam senyawa nutrisi bermanfaat untuk mencegah efek oksidatif yang timbul karena inflamasi jaringan akibat infeksi sehingga menyebabkan kerusakan jaringan (Solomon, 2007).

Keadaan malnutrisi dapat menyebabkan gangguan sistem imun. Timus adalah salah satu organ limfoid primer yang memproduksi sel $\mathrm{T}$ yang berperan dalam mekanisme pertahanan tubuh dari benda asing. Kekurangan protein dalam kondisi malnutrisi dapat menyebabkan atrofi timus sehingga tidak bisa bekerja melawan benda asing yang masuk termasuk bakteri penyebab pneumonia (Bourke et al., 2016).

Peneliti menyimpulkan bahwa status gizi baik menurunkan risiko pneumonia balita karena kekebalan tubuh yang baik dalam melawan agen penyebab penyakit.

\section{Pengaruh ASI eksklusif terhadap kejadian pneumonia balita.}

Penelitian ini menunjukkan bahwa terdapat pengaruh secara langsung antara ASI eksklusif dengan kejadian pneumonia balita. Hasil ini didukung Ni Kadek Nira et al., (2013) bahwa peran ASI eksklusif dapat menurunkan kejadian pneumonia sebesar 3.39 kali $(\mathrm{OR}=-3.39$; CI 95\%=1.85 hingga 8.59; $\mathrm{p}<0.001)$. Lamberti et al., (2013) menyatakan bahwa anak usia 0-5 bulan yang tidak mendapatkan ASI eksklusif berisiko terkena pneumonia 14.97 kali lebih besar $\quad(\mathrm{OR}=14.97$; CI $95 \%=0.67$ hingga 332.74), sedangkan untuk anak usia 6-23 yang tidak mendapatkan ASI eksklusif berisiko terkena pneumonia 1.92 kali lebih besar (CI 95\%= 0.79 hingga 4.68).

Pemberian ASI sangat berperan dalam meningkatkan sistem kekebalan tubuh karena kandungan berbagai macam antiinfeksi dan berbagai senyawa imun. Senyawa imunitas adaptif yang terdapat dalam ASI, contohnya Immunoglobulin sIgA, IgG, IgM, IgE, IgD, dan free secretory component, sedangkan senyawa imunitas alami antara lain komplemen, chemotactic factors, properdin factors, interferon, afetoprotein, antistaphylococci factors, 
Journal of Maternal and Child Health (2017), 2(2): 162-175

https://doi.org/10.26911/thejmch.2017.02.02.07

mannose binding lectin,b-defensin-1, antiadherence substances (oligosaccharides, mucins, lactadherin, glycolipids dan glycosaminoglycans, k-casein), milk fat globule, dan growth factors (prolactin, kortisol, insulin, thyroxin, prostaglandin, vascular endothelial growth factor, nerve growth factor, TGF, erythropoietin), dan antiviral factors (fatty acids and monoglycerides), migration inhibition factor, a-lactalbumin (Chirico et al., 2012).

Peneliti menyimpulkan bahwa ASI eksklusif merupakan faktor protektif terhadap pneumonia karena kandungan ASI yang dapat meningkatkan sistem imun balita sehingga dapat menurunkan kejadian pneumonia balita.

\section{Pengaruh BBLR terhadap kejadian pneumonia balita.}

Penelitian ini menunjukkan bahwa terdapat pengaruh antara BBLR dengan kejadian pneumonia balita. Penelitian oleh Martin et al., (2015) di Brazil, menyebutkan bahwa anak yang mempunyai riwayat BBLR (berat lahir $<2,500$ gram) berisiko terkena pneumonia sebesar 5.86 kali lebih besar daripada anak dengan berat lahir $\geq 2,500$ gram (CI 95\%=1.75 hingga 20.40).

Bayi dengan berat lahir mempengaruhi status gizi anak karena merupakan salah satu faktor penyebab terjadinya malnutrisi anak. Penelitian oleh Rahman et al., (2016) di Bangladesh, mendukung bahwa BBLR meningkatkan risiko kejadian malnutrisi yaitu kejadian stunting sebesar 1.23 kali (CI $95 \%=1.16$ hingga 1.30), kejadian wasting: 1.71 kali (CI95\%=1.53 hingga 1.92) dan kejadian underweight 1.47 kali (CI95\%: 1.38 hingga 1.56).

Bayi dengan BBLR berisiko mengalami gangguan pertumbuhan, seperti pada penelitian Nguyen et al., (2013) menyebutkan bahwa bayi dengan BBLR sulit mencapai berat badan maupun tinggi badan yang optimal sampai usia 24 bulan. BBLR ini merupakan faktor intermediet pertumbuhan anak yang merupakan indikator status gizi anak, sedangkan yang menjadi underlying factor adalah pendidikan ibu, pekerjaan ibu, dan ekonomi keluarga (Nguyen et al., 2013). Hal ini mendukung bahwa BBLR berkaitan dengan status gizi anak yang dapat menjadi faktor risiko secara tidak langsung kejadian pneumonia balita. Bayi dengan BBLR cenderung meningkatkan kasus gizi kurang yang berakibat sistem imunitas balita menurun dan mudah terjadi infeksi pernafasan seperti pneumonia (Ramezani et al., 2015).

BBLR dipengaruhi oleh pendapatan keluarga dan pendidikan ibu (Govern, 2013). Pendapatan keluarga yang tinggi membuat keluarga mampu memenuhi kebutuhan sehari-hari dengan baik termasuk kebutuhan nutrisi untuk ibu hamil, sehingga kebutuhan kalori ibu hami yang tercukupi dapat mengurangi kejadian BBLR. Pendidikan ibu juga mempengaruhi kejadian BBLR karena ibu dengan pendidikan yang tinggi mempunyai pengetahuan yang cukup untuk menjaga kehamilan yang sehat dan mengurangi risiko BBLR.

\section{Pengaruh stres ibu terhadap keja- dian pneumonia balita}

Penelitian ini menunjukkan bahwa terdapat pengaruh antara stres ibu dengan kejadian pneumonia balita. Ibu dengan stres psikologis yang tinggi dapat menjadi rentan apabila ibu tidak melakukan coping dengan baik. Hal ini menimbulkan pengaruh psikologis juga terhadap anak. Anak dengan stres psikologis ini dapat berakibat menurunnya sitem imun dalam tubuhnya, sehingga mudah terkena penyakit. Penelitian Vermeer et al., (2011) menganalisis pengaruh stres terhadap kekebalan tubuh anak yang dibesarkan dengan pengasuhan keluarga yang mengalami stres dan tidak stres. Hasilnya menunjukkan bahwa sIgA (Secretory Immunoglobulin A) anak menu- 
run pada anak yang dirawat dengan kurang baik karena adanya stres dalam keluarga.

Penelitian Han et al., (2015) mendukung bahwa stres ibu dapat menurunkan efikasi diri ibu dalam kasus pneumonia sebesar 0.65 kali lebih besar daripada yang tidak stres $(\mathrm{p}<0.001)$. Stres psikologis pada seorang ibu dapat mempengaruhi pola asuh terhadap anak. Seorang balita belum mampu memenuhi kebutuhannya sendiri, sehingga peran ibu dalam pengasuhan anak sangat penting. Stres ibu dapat menyebabkan peran sebagai seorang ibu menjadi terganggu. Hal ini yang menyebabkan maltreatment bahkan sampai terjadi penelantaran terhadap anak. Ibu menjadi tidak bisa fokus dalam mengurus anak sehingga tidak bisa memperhatikan kebutuhan dasar yang baik bagi anak seperti pakaian, lingkungan yang bersih, makanan yang bernutrisi. Seorang ibu perlu mempumyai kepercayaan diri dalam merawat anak.

Penelitian Islam et al., (2011) tentang dampak stres terhadap gangguan saluran pernafasan membuktikan bahwa anak penderita asma yang tumbuh dalam keluarga yang mengalami tingkat stres tinggi mengalami lebih rentan mengalami penurunan fungsi paru akibat paparan polusi udara lebih besar 4.5 kali daripada anak yang dibesarkan dalam keluarga dengan tingkat stres rendah (CI $95 \%=-6.5$ hingga -2.4 ).

Pengaruh stres ibu juga mempengaruhi pemberian ASI eksklusif. Mekanisme mengenai stres ibu terhadap pemberian ASI eksklusif belum jelas. Kemungkinan bahwa adanya stres mempengaruhi mood sehingga hormon oksitosin yang bekerja untuk produksi ASI berkurang. Penelitian Dozier et al., (2012) menjelaskan berbagai peristiwa pemicu stres dan hubungannya dengan pemberian ASI. Stres karena permasalahan dengan pasangan menunjukkan hasil signifikan dimana stres meningkatkan penghentian ASI dalam 13 minggu pertama sebesar 3.94 kali (CI 95\%= 1.61 hingga 9.61; $\mathrm{p}<0.010$ ).

Dozier yang menyebutkan berbagai penyebab stres mempengaruhi penghentian pemberian ASI. Stres karena masalah ekonomi keluarga mempengaruhi pemberian ASI eksklusif dalam 13 minggu pertama sebesar 1.55 kali (CI 95\%= 0.32 hingga 2.89; $\mathrm{p}=0.17$ ). Peneliti berpendapat bahwa ibu dengan tingkat stres tinggi yang bisa melakukan coping stres dengan baik akan bisa beradaptasi dengan stres dan tidak mempengaruhi mood ibu dalam memberikan ASI eksklusif.

\section{Pengaruh pendapatan keluarga terhadap kejadian pneumonia balita.}

Penelitian ini menunjukkan bahwa terdapat pengaruh antara pendapatan keluarga dengan kejadian pneumonia balita. Pendapatan keluarga berperan dalam kejadian pneumonia didukung oleh Azab et al., (2014) membuktikan bahwa pendapatan keluarga yang rendah meningkatkan kejadian pneumonia sebesar 2.2 kali (CI 95\%=0.99 hingga 4.78; p=0.047). Kosai et al., (2015) juga membuktikan bahwa tingkat pendapatan keluarga yang rendah meningkatkan kejadian pneumonia balita sebesar 1.11 (CI 95\%= 1.02 hingga 1.20).

Faktor sosioekonomi merupakan faktor penting dalam kejadian pneumonia berkaitan dengan status gizi (Mahmud, 2009). Pendapatan keluarga yang tinggi berpengaruh terhadap pemenuhan kebutuhan pangan dengan baik sehingga bisa menjamin nutrisi yang optimal. Kebutuhan nutrisi yang tercukupi menyebabkab status gizi anak menjadi baik. Status gizi yang baik ini yang merupakan faktor protektif terhadap kejadian pneumonia karena status gizi yang baik menyebabkan imun tubuh bekerja dengan baik pula.

Pendapatan perkapita menggambarkan kemampuan ekonomi seseorang yang secara luas berpengaruh terhadap aspek- 
aspek kehidupan lainnya, seperti perilaku sehat, pendidikan, perumahan dan lainnya. Keluarga dengan pendapatan perkapita tinggi dapat memenuhi kebutuhan anggota keluarganya,seperti kebutuhan gizi, tempat tinggal yang sehat dan pemeliharaan kesehatan (Sweeting dan Hunt 2014).

Pendapatan keluarga juga mempengaruhi pemberian ASI eksklusif. Keluarga yang berpendapatan tinggi menjamin asupan gizi yang baik bagi seorang ibu yang menyusui, sehingga bisa memberikan ASI eksklusif kepada bayinya. Pemberian ASI eksklusif dapat menurunkan kejadian pneumonia pada balita.

Pendapatan keluarga dapat mempengaruhi kejadian BBLR, hal ini dikarenakan dalam keluarga yang berpendapatan tinggi menjamin asupan kalori dan nutrisi penting lainnya bagi ibu hamil, sehingga risiko melahirkan bayi dengan berat badan lahir $<2,500$ gram menurun.

\section{Pengaruh pendidikan ibu terhadap kejadian pneumonia balita.}

Penelitian ini menunjukkan bahwa terdapat pengaruh antara pendidikan keluarga dengan kejadian pneumonia. Pendidikan memang menjadi suatu fondasi penting dalam keluarga terutama pendidikan seorang ibu. Ibu dengan tingkat pendidikan tinggi dapat menjalankan peran di dalam keluarga dengan baik karena dengan pendidikan yang tinggi bisa meningkatkan pengetahuan mengenai kesehatan, gizi keluarga, lingkungan rumah, dan perilaku terkait pencegahan maupun promosi kesehatan lainnya (Ramezani et al., 2015; Feinberg et al., 2016).

Pendidikan berpengaruh secara langsung terhadap pneumonia, hal ini didukung penelitian Azab et al., (2014) dimana pendidikan rendah menaikkan risiko pneumonia yang berat yaitu sebesar 3.8 kali (CI $95 \%=2.12$ hingga $6.70 ; \mathrm{p}=0.001)$. Pradhan et al., (2016) juga menunjukkan pengaruh level pendidikan ibu dengan kejadian pneumonia $(p<0.001)$. Semakin tinggi pendidikan ibu semakin meningkatkan pengetahuan ibu tentang pneumonia dan cara mendeteksi dini gejalanya. Hal ini sangat berperan dalam mengurangi morbiditas dan mortalitas pneumonia balita.

Seorang ibu memegang peran penting dalam pola asah, asih dan asuh anak. Pendidikan ibu yang baik meningkatkan kemampuan untuk menerima informasi tentang bagaimana menjaga kesehatan keluarga, mendidik anak dan peduli dengan tumbuh kembang anak (Soetjiningsih, 2012). Disebutkan didalam laporan UNESCO bahwa beberapa capaian penting upaya peningkatan pendidikan pada ibu dapat mengurangi angka kematian ibu dan anak, meningkatkan status gizi masyarakat dan berbagai pencegahan terhadap penyakit (Liu et al., 2015).

Kualitas sumber daya manusia tergantung dari kualitas pendidikannya. Pendidikan mempunyai andil besar terhadap kemajuan ekonomi suatu bangsa. Penting menyiapkan sumber daya manusia yang terdidik guna mencapai kemajuan di bidang ekonomi (Phelan et al., 2010).

\section{Pengaruh pekerjaan ibu terhadap kejadian pneumonia balita.}

Penelitian ini menunjukkan bahwa terdapat pengaruh antara pekerjaan ibu dengan kejadian pneumonia terkait dengan ASI eksklusif. Ibu yang bekerja di luar rumah mempunyai risiko tidak memberikan ASI secara eksklusif. Penelitian ini didukung oleh Dagher et al., (2016) di Amerika Serikat, sebagai negara industri terbesar dengan angka menyusui yang rendah, memperlihatkan bahwa ibu yang bekerja di luar rumah/pekerja kantoran berisiko lebih tinggi tidak bisa memberikan ASI eksklusif sebesar 1.46 kali lebih besar daripada ibu yang berhenti kerja di kantor (CI 95\% $=1.14$ hingga 1.87; $\mathrm{p}<0.010$ ). Ibu yang bekerja di 
luar rumah menyebabkan durasi pemberian ASI berkurang, meskipun banyak kantor yang ramah ASI yang menyediakan tempat untuk menyusui/pojok laktasi. Penelitian ini menunjukkan bahwa pneumonia dipengaruhi oleh pemberian ASI eksklusif yaitu menurunkan kejadian pneumonia. Pengurangan durasi pemberian ASI eksklusif karena ibu bekerja dapat meningkatkan kejadian pneumonia.

8. Pengaruh lingkungan rumah terhadap kejadian pneumonia balita.

Penelitian ini menunjukkan bahwa terdapat pengaruh antara lingkungan rumah dengan kejadian pneumonia. Hal ini didukung oleh Sugihartono dan Nurjazuli (2012) bahwa kondisi rumah yang tidak memenuhi syarat menjadi faktor yang meningkatkan kejadian pneumonia termasuk balita yang mendapatkan pengaruh paparan asap rokok. Pencemaran asap rokok dari kondisi passive smoking yang berasal dari orang tua atau orang dewasa serumah di lingkungannya. Charoenca et al., (2013) menunjukkan kejadian pneumonia meningkat pada balita yang terpapar asap rokok dalam rumah dengan dengan OR sebesar 3.82 (CI 95\%= 2.47 hingga 5.9).

Zheng et al., (2012) di China membuktikan bahwa faktor lingkungan dalam rumah yang berhubungan dengan kejadian pneumonia adalah kelembaban, kurangnya ventilasi, penggunaan batu bara dalam memasak meningkatkan kejadian pneumonia.

Faktor lingkungan berpengaruh besar terhadap penyakit-penyakit pernapasan. Polusi udara merupakan bahan kajian penting karena manusia tidak dapat menghindar dari bahan hirup yang ada di lingkungan seperti partikel debu, gas, atau uap. Kegiatan memasak dengan berbagai jenis alat memasak dan jenis bahan bakarnya mempengaruhi kejadian penyakit pneumonia akibat asap yang dihasilkannya (Bruce et al., 2013).
Peneliti menyimpulkan bahwa faktor lingkungan rumah sangat berperan dalam terjadinya pneumonia balita sehingga perlu dijaga lingkungan untuk melindungi balita dari ancaman pneumonia.

\section{REFERENCE}

Azab SFAH, Sherief LM, Saleh SH, Elsaeed WF, Abdelsalam MAES (2014). Impact of the socioeconomic status on the severity and outcome of community-acquired pneumonia among Egyptian children: a cohort study. Infectious Diseases of Poverty, 3(14).

Bruce NG, Dherani MK., Das JK, Balakrishnan K, Rohani HA, Bhutta, ZA dan Pope D (2013). Control of household air pollution for child survival: estimates for intervention impacts. BMC Public Health, 13(3): 1-13.

Bourke CD, Berkley JA, Prendergast AJ (2016). Immune Dysfunction as a Cause and Consequence of Malnutrition. Trends in Immunology, 37(6): 386-398.

Charoenca N, Kungskulniti, Tipayamongkholgul K, Sujirarat D (2013). Determining the burden of secondhand smoke exposure on the respiratory health of Thai children. Biomed Central, 11(7): 1-7.

Chirico G, Marzollo R, Cortinovis S, Fonte C, Gasparoni A (2012). Antiinfective Properties of Human Milk. The Journal of Nutrition Influence of Diet on Infection and Allergy in Infants, 138: 1801S-1806S.

Dagher RK, McGovern PM, Schold JD Randall XJ (2016). Determinants of breastfeeding initiation and cessation among employed mothers: a prospective cohort study. BMC Pregnancy and Childbirth, 16:194.

Dinas Kesehatan Kota Surakarta (2014). Profil Kesehatan Kota Surakarta 
Tahun 2014. Surakarta.

Dozier AM, Nelson A, Brownell E (2012). The Relationship between Life Stress and Breastfeeding Outcomes among Low Income Mothers. Advances in Preventive Medicine. Hindawi Publishing Corporation.

Feinberg I, Frijters, Lawrence JJ, Greenberg V, Greenberg D, Nightingale E, Moodie C (2016). Examining Associations between Health Information Seeking Behavior and Adult Education Status in the US : An Analysis of the 2012 PIAAC Data. Plos One, 11(2): $1-20$.

Ghimire M, Bhattacharya SK, Narain JP (2012). Pneumonia in South-East Asia Region: Public health perspective. The Indian Journal of Medical Research, 135(4): 459-468.

Govern ME (2013). Still Unequal at Birth: Birth Weight, Socioeconomic Status and Outcomes at Age 9 The Economic and Social Review, 44(1): 53-84.

Han NT, Pongjaturawita Y, Chaimongkola Y (2015). Factors Related to Self-Efficacy in Caring for Young Children with Pneumonia among Vietnamese Mothers. Proceedings of the Burapha University International Conference 2015, 10-12 July 2015, Bangsaen, Chonburi, Thailand: 323-330.

Hadisuwarno W, Setyoningrum RA, Umiastuti P (2015). Host factors related to pneumonia in children under 5 years of age. Paediatrica Indonesiana, 55(5): 248.

Hatala AR (2012). The Status of the "Biopsychosocial" Model in Health Psychology": Towards an Integrated Approach and a Critique of Cultural Conceptions. Open Journal of Medical Psychology, 1: 51-62.

Islam $\mathrm{T}$, Urman $\mathrm{U}$, Wgauderman $\mathrm{WJ}$, Milam J, Lurmann F, Shankardass K,
Ed Avol, Gilliland F, and McConnel R (2011). Parental Stress Increases the Detrimental Effect of Traffic Exposure on Children's Lung Function. American Journal Respiratory Crittical Care Medicines, 184: 822-827.

Jackson S, Mathew KH, Pulanic D, Falconer R, Rudan I, Campbell H, Nair H (2013). Risk factors for severe acute lower respiratory infections in children - a systematic review and metaanalysis. Croatian Medical Journal (CMJ), 54: 110-121.

Kementerian Kesehatan RI (2015). Profil Kesehatan Indonesia 2015. Jakarta.

Kosai H, Tamaki R, Saito M, Tohma K, Alday PP, Tan AG (2015). Incidence and Risk Factors of Childhood Pneumonia-Like Episodes in Biliran Island, Philippines-A CommunityBased Study. PLoS ONE 10(5): e0125009.

Liu YB, Li YF, Chen YL, Li Y (2015). Relationship between Health Literacy, Health-Related Behaviors and Health Status: A Survey of Elderly Chinese. Int. J. Environ. Res. Public Health, 12: 9714-9725.

Lamberti LM, Grković IZ, Walker CF, Theodoratou E, Nair H,Campbell H, Black RE (2013). Breastfeeding for reducing the risk of pneumonia morbidity and mortality in children under two:a systematic literature review and metaanalysis. BMC Public Health, 13(3): S18.

Mahmud R (2009). Pengaruh Kemiskinan Keluarga pada Kejadian Pneumonia Balita di Indonesia. Jurnal Kesehatan Masyarakat Nasional, 4(1).

Martins ALO, Nascimento DS, Schneider IJS, Trevisol FS (2015). Incidence of community-acquired infections of lower airways among infants. Pediatrica. 34(2): 204-209. 
Nira NK, Pramono D, Naning R (2013). Risk Factors of Pneumonia Among Under Five Children in Purbalingga District, Central Java Province. Tropical Medical Journal (TMJ), 3(2): 128135 .

Nguyen HT, Eriksson B, Petzold M, Bondjers G, Tran TK, Nguyen LT, Ascher H (2013). Factors associated with physical growth of children during the first two years of life in rural and urban areas of Vietnam. BMC Pediatrics, 13: 149.

Pradhan SM, Rao AP, Pattanshetty SM Nilima AR (2016). Knowledge and perception regarding childhood pneumonia among mothers of under-five children in rural areas of Udupi Taluk, Karnataka: A cross-sectional study. Indian Journal of Health Sciences. 3539.

Phelan JC, Link BG, Tehranifar P (2010). Social Conditions as Fundamental Causes of Health Inequalities: Theory, Evidence, and Policy Implications. Journal of Health and Social Behavior, 51(S): 28-40.

Rahman MS, Howlader T, Masud MS, Rahman ML (2016). Association of LowBirth Weight with Malnutrition in Children under Five Years in Bangladesh: Do Mother's Education, SocioEconomic Status, and Birth Interval Matter? Plos One.

Ramezani M, Aemmi SZ, Moghadam ZE (2015). Factors Affecting the Rate of Pediatric Pneumonia in Developing Countries: a Review and Literature Study. International Jounal of Pediatrics, 3(24).

Riskesdas (2013). Riset Kesehatan Dasar. Jakarta: Badan Penelitian Dan Pengembangan Kesehatan Kementerian Kesehatan RI.

Rudan I, Pinto CB, Biloglav Z, Mulholland
K, Campbelle H (2008). Epidemiology and etiology of childhood pneumonia. Bulletin of the World Health Organization, 86: 408-416.

Sugihartono, Nurjazuli (2012). Analisis Faktor Risiko Kejadian Pneumonia Pada Balita Di Wilayah Kerja Puskesmas SidorejoKota Pagar Alam. Jurnal Kesehatan Lingkungan Indonesia 11(1).

Solomon NW (2007). Malnutrition and infection: an update. British Journal of Nutrition, 98: $\mathrm{S}_{5}-\mathrm{S} 10$.

Soetjiningsih (2012). Faktor-faktor yang Mempengaruhi Tumbuh Kembang dalam Tumbuh Kembang Anak Edisi Kedua. Soetjiningsih dan Gde Ranuh (editor). Jakarta: Penerbit Buku Kedokteran EGC, 61-72.

Sweeting H, Hunt K ( 2014). Social Science \& Medicine Adolescent socio-economic and school-based social status. Health and Social Science \& Medicine, 121: 39-47.

Vermeer HJ, IJzendoorn MH, Groeneveld MG, Granger DA (2011). Downregulation of the immune system in lowquality child care: The case of Secretory Immunoglobulin A (SIgA) in toddlers. Physiology \& Behavior, 105: 161-167.

WHO (2016). Pneumonia The Forgotten Killer of children. New York- USA: WHO Press.

Zheng X H, Qian H, Zhao Y L, Shen HP, Zhao ZH, Sun XY, dan Sundell J (2013). Home risk factors for childhood pneumonia in Nanjing, China. Chinese Science Bulletin, 58: 42304236. 